\title{
Nitrogen Supplementation on the Productivity and the Chemical Composition of Oyster Mushroom
}

\author{
Mateus Dias Nunes, José Maria Rodrigues da Luz, Sirlaine Albino Paes, João Júlio Oliveira Ribeiro, Marliane \\ de Cássia Soares da Silva \& Maria Catarina Megumi Kasuya \\ BIOAGRO, Departament of Microbiology, Federal University of Viçosa \\ Campus Universitário, Viçosa 36570-000, MG, Brazil \\ Tel: 55-031-3899-2970_E-mail: mkasuya@ufv.br
}

Received: February 28, 2012

Accepted: March 30, 2012 Published: May 1, 2012

doi:10.5539/jfr.v1n2p113

URL: http://dx.doi.org/10.5539/jfr.v1n2p113

\begin{abstract}
Mushrooms have been used for food and medicinal purposes since ancient period. The $\beta$-glucans found in mushrooms are currently considered to be responsible for some of the medicinal properties of mushrooms, thereby motivating studies on characterization of these compounds. In our study, we tested the effect of nitrogen supplementation on the productivity and nutritional composition of Pleurotus ostreatus mushrooms. The fungi were grown in various substrates supplemented with urea or rice bran, and the biological efficiency, mineral composition, protein and $\beta$-glucan content were evaluated. The growth of $P$. ostreatus in substrates with nitrogen supplementation increases the mushroom's productivity and nutritional value. Our results also indicate that nitrogen supplementation, a simple technique, efficiently increases the $\beta$-glucan content of mushrooms.
\end{abstract}

Keywords: Rice bran, Urea, Biological Efficiency, Bioactive polysaccharides

\section{Introduction}

Mushrooms are becoming increasingly important and common in human diets, due to their nutritional (Barros, Cruz, Baptista, Estevinho \& Ferreira, 2008; Bernaś, Jaworska \& Lisiewska, 2006) and medicinal characteristics (Jedinak, Dudhgaonkar, Jiang, Sandusky \& Sliva, 2010). The nutritional advantages of mushrooms include a low content of calories and a high content of proteins, minerals and dietary fiber (Beluhan \& Ranogajec, 2011). As dietary food, mushrooms are comparable to vegetables. Also, mushrooms are a good source of protein, containing all of the essential amino acids, which allows mushrooms to serve as a meat substitute. Moreover, mushrooms have high vitamin B content and a low lipid content, which renders them nutritionally ideal for people who have heart problems (Ghorai, Banik, Verma, Chowdhury, Mukherjee \& Khowala, 2009).

In the last decades, an increasing number of studies on mushrooms have been conducted, wich have been demonstrated the powerful properties of compounds extracted from mushrooms. Among these compounds, $\beta$-glucan have received considerable attention because of their medicinal properties, such as their ability to enhance macrophage functions, activate nonspecific immune responses, reduce cancer occurrences and developments (Jedinak et al., 2010; Wasser, 2011).

To improve the productivity and nutritional value of mushrooms several techniques, substrates, cultivation conditions and strains have been tested. Some studies show that supplementation with nitrogen source increase the biomass and mushroom's productivity (Curvetto, Figlas, Devalis \& Delmastro, 2002; Buswell, Cai \& Chang, 1995; Shashirekha, Rajarathnam \& Bano, 2005). However, in the literature no studies related to increase $\beta$-glucans content in mushrooms was found. In this study we compare the addition of organic and inorganic nitrogen source on the productivity, $\beta$-glucan content, protein concentration and mineral composition of $P$. ostreatus mushrooms.

\section{Material and Method}

\subsection{Microorganisms and inoculum production (spawn)}

Pleurotus ostreatus strains (PLO 6 and PLO 2) were obtained from the Federal University of Viçosa and were maintained in Petri dishes containing potato dextrose agar (PDA) medium at $22{ }^{\circ} \mathrm{C}$. Wheat grains were used as a substrate for the spawn. The grains were cooked for $30 \mathrm{~min}$ in water at a 1:3 ratio of wheat grains:water (w/w). 
After cooking, the grains were drained and supplemented with $0.35 \% \mathrm{CaCO}_{3}$ and $0.01 \% \mathrm{CaSO}_{4}$. These grains $(70 \mathrm{~g})$ were packed into small glass jars and were sterilized in an autoclave at $121^{\circ} \mathrm{C}$ for $90 \mathrm{~min}$. After cooling, each jar was inoculated with 4 agar discs, $5 \mathrm{~mm}$ diameter, containing mycelium, and the jars were incubated in the dark, at room temperature, for $15 \mathrm{~d}$.

\subsection{Substrates and environmental conditions for mushroom production}

The following substrates were obtained from local farms and were used for this study: eucalypt sawdust, corncobs, eucalypt bark, coffee husks and sugarcane bagasse (Table 1). Except for the control substrate, which lacked supplementation, all of the substrates were supplemented with $20 \%$ rice bran $(\mathrm{w} / \mathrm{w})$ or $0.5 \%$ urea $(\mathrm{w} / \mathrm{w})$. All of the substrates except the coffee husks were crushed and passed through a $0.5-\mathrm{mm}$ sieve. The coffee husks were boiled for $2 \mathrm{~h}$ and were centrifuged, $1800 \mathrm{rpm}$ x $5 \mathrm{~min}$ (Silva et al., 2012). The substrates were humidified until a moisture content of $70 \%$ was reached. The substrates were packed into polyethylene bags and were sterilized twice in an autoclave at $121{ }^{\circ} \mathrm{C}$ for $90 \mathrm{~min}$. After sterilization, each bag was inoculated using $70 \mathrm{~g}$ of spawn and was incubated in the dark at room temperature for $20 \mathrm{~d}$.

\subsection{Mushroom harvesting}

After incubation period, the bags were transferred to a cultivation chamber at $25 \pm 2{ }^{\circ} \mathrm{C}$ and $90 \%$ relative air humidity in the presence of light throughout the entire harvesting period. The mushrooms were harvested at maximum development but with the hat closed. The mushrooms were weighed to determine their biological efficiency (BE), which was calculated with the following equation: $\mathrm{BE}=$ (fresh mass of mushroom / dry mass of substrate) $\times 100$.

\subsection{Nutritional composition}

For mineral content determination, the dried mushrooms were triturated and submitted to nitroperchloric digestion (Tedesco, Gianello, Bissani, Bohnen, \& Volkweiss; 1995). Phosphorus content was determined by a colorimetric method (Murphy \& Riley, 1962). The mushrooms' calcium and magnesium contents were determined by atomic absorption spectrometry, and potassium content was measured by flame spectrometry (Thiers \& Hviid, 1962). Total protein content was determined by the Kjeldahl method using a conversion factor of 4.38 (Guo, Lin \& Lin, 2007). Soluble protein content was determined with a colorimetric method (Bradford, 1976) using bovine serum albumin as a standard. All analyses were performed in duplicate.

$\beta$-glucan content was performed in triplicate according to the methodology employed by Park, Ikegakim, Alencar, \& Aguiar (2003). The concentration of $\beta$-glucan in the mushrooms was calculated with the following equation: $\beta$-glucan $(\mathrm{g} 100 \mathrm{~g}-1)=$ glucose $(100 \mathrm{~g}-1) \times 0.9$. The correction factor of 0.9 takes into account the structural differences between free glucose and $\beta$-glucan.

\subsection{Statistical analysis}

The experiment was designed in completed and randomized blocks with five replicates. The data were subjected to analysis of variance and mean values were compared by Tukey's test $(\mathrm{p}<0.05)$ using Saeg software (version 9.1, Federal University of Viçosa).

\section{Results}

Regardless of the substrate used for cultivation, supplementation with nitrogen increased the mushrooms' BEs (Figure 1). The highest BE was achieved with rice bran supplementation, especially when the mushrooms' substrates were based on sugarcane bagasse and eucalypt bark. When rice bran and urea supplementation were compared, the best results were yielded by rice bran supplementation, especially when sugarcane bagasse, corncobs and coffee husks were used as substrates (Figure 1).

The influence of nitrogen supplementation on the level of mineral absorption was directly related to the composition of the substrate (Table 2). The supplementation of substrates with rice bran affected positively the level of phosphorus absorption while urea supplementation affected negatively.

For most substrates, nitrogen supplementation did not affect the percentages of protein in the mushrooms (Table 3). However, urea supplementation decreases the protein content in both strains when they were cultivated in eucalypt sawdust. Furthermore, the protein content of PLO 2 strain grown in sugarcane bagasse supplemented with urea increased $33.60 \%$ compared to the control, and the protein content of the PLO 6 strain grown in sugarcane bagasse or eucalypt bark supplemented with rice bran decreased 32.77 and $19.05 \%$, respectively, compared to the control (Table 3).

Urea supplementation increased the soluble protein content increased $8.72 \%$ compared to the control, and the $\beta$-glucan content increased $20.87 \%$ with rice bran and $17.65 \%$ with urea supplementations (Table 4 ). 


\section{Discussion}

Nitrogen supplementation enhanced mushroom BE, especially when organic sources were used (Figure 1). The supplementation of the substrates with various sources of organic nitrogen, such as wheat bran, rice bran, maize wastewater, soya cake powder and rice, has increased the BEs of various species of basidiomycetes (Loss, Royer, Barreto-Rodrigues, \& Barana, 2009, Moonmoon, Shelly, Khan, Uddin, Hossain, Tania, \& Ahmed, 2011). Organic sources of nitrogen can be easily used by fungi because the absorption of these molecules is more energetically efficient than synthesizing the molecules, which allow the fungi to obtain more energy for mycelial growth and mushroom formation. The BE increase can be due to the high availability of water in substrate add with rice bran (Figure 1), since addition of rice bran decreases the granulometry of substrate, which improve the moisture retention (Özçelik \& Peksen, 2007). For mushroom formation, the fungus requires a considerable amount of water, due to the high content of water in mushrooms (Tewari, 1986).

The BE values observed in our study (Figure 1) were similar to observed in other basidiomycetes, which ranges from 18.9 to 100\% (Jafarpour, Zand, Dehdashtizadeh \& Eghbalsaied, 2010; Loss, et al., 2009; Wang, Sakoda \& Suzuki, 2001).

In general, supplementation of the substrates with rice bran did not affect the mineral content of the mushrooms (Table 2). However, the uptake of phosphorus increased for most substrates, which may be a result of the elevated levels of phosphorus in the rice bran (Özçelik \& Peksen, 2007). Thus, the increase in the mushrooms' productivity did not impair the mineral composition of the mushrooms (Table 2 and Figure 1). Furthermore, addition of urea inhibits the assimilation of phosphorus, potassium and magnesium in some substrates (Table 2). Such downregulation has also been reported for the assimilation of $\mathrm{Mg}$ and $\mathrm{K}$ in plants (Khan, Watanabe, \& Watanabe, 2000). Urea may act as a chelator, decreasing the availability of minerals. Further, nitrogen supplementation did not affect calcium concentrations, which is in agreement with reports that calcium does not bioacumulated in mushrooms (Kalac, 2009).

The protein content of mushrooms depends on several factors, such as substrate chemical composition, pileus size, cultivation time and strain (Bernaś, et al., 2006). The mushroom protein contents that were found in this study (Table 3) are in agreement with the range of mushroom protein contents reported in the literature (Bernaś, et al., 2006; Papaspyridi, Katapodis, Gonou-Zagou, Kapsanaki-Gotsi \& Christakopoulos, 2010; Tshinyangu \& Hennebert, 1996) varying between 17 and $42.5 \%$, dependent on the correction factor $(4.38,6.25$ or 6.38$)$. These values were influenced by chemical composition of substrate, which reinforces the necessity of selecting suitable substrates and, in some cases, suitable nitrogen supplementation (Table 3).

Similar to the protein content, soluble protein in fungi also depend on the chemical composition of the substrate and fungus strain, varying between 5 and $14 \mathrm{mg} \mathrm{g-1} \mathrm{(Membrillo,} \mathrm{Sánchez,} \mathrm{Meneses,} \mathrm{Favela} \mathrm{\&} \mathrm{Loera,} \mathrm{2011;} \mathrm{Paul,}$ Singh, Tyagi, Singh \& Dubey, 2010). The protein contents found in our study were slightly greater than the previously published values (Table 4). In both strains, urea supplementation increased the soluble protein content. These results were in keeping with theoretical predictions stating that increase in the availability of nitrogen may enable increase protein contents of plants, animals and fungi (Chandel, Banerjee, See, Meena, Sharma \& Verulkar, 2010; Ferrise, Triossi, Stratonovitch, Bindi \& Martre, 2010; Janicki, Holter \& Hayes, 1985; Membrillo, Sánchez, Meneses, Favela \& Loera, 2008).

The percentages of $\beta$-glucans found in this study were less (Table 3) than reported in the literature (Carbonero, Gracher, Smiderle, Rosado, Sassaki, Gorin, et al., 2006; Manzi \& Pizzoferrato, 2000; Papaspyridi, et al., 2010), which range around $38 \%, 39 \%$ and $53 \%$, in P. ostreatus, P. eryngii and P. pulmunarius, respectively. However, values lower than $30 \%$ have been found in $P$. ostreatus (Papaspyridi, et al., 2010). The low value observed in our study can be attributed to the physiological characteristic of our isolates.

Functional foods represent one of the most interesting areas of research and innovation in the food industry (Arias-Aranda \& Romerosa-Mártinez, 2010). According to these authors, functional foods may help to prevent disease, reduce the risk of developing disease, or enhance health. Mushrooms represent an unlimited source of polysaccharides, mainly $\beta$-glucans, with antitumor and immunostimulating properties (Wasser, 2002). Thus, studies about $\beta$-glucans content in mushrooms are important, since these compounds are beneficial to health. Our results indicate that nitrogen supplementation, a simple technique, efficiently increases the $\beta$-glucan content in the mushrooms. So, P. ostreatus mushroom cultivated in substrate supplemented with nitrogen is a good food source containing protein, minerals and bioactive compound, such as $\beta$-glucans. 


\section{Conclusions}

This study shows that the cultivation of $P$. ostreatus in substrates supplemented with nitrogen is a simple technique to increases the productivity and $\beta$-glucans content in mushrooms. The use of rice bran increases the productivity of mushrooms more than urea supplementation does.

\section{Acknowledgments}

The authors are very grateful to Brazilian financial Institutions: CAPES, CNPq and FAPEMIG.

\section{References}

Arias-Aranda, D., \& Romerosa-Martínez, M. M. (2010). Innovation in the functional foods industry in a peripheral region of the European Union: Andalusia (Spain). Food Policy, 35, 240-246. http://dx.doi.org/10.1016/j.foodpol.2009.12.008

Barros, L., Cruz, T., Baptista, P., Estevinho, L. M., \& Ferreira, I. C. F. R. (2008). Wild and commercial mushrooms as source of nutrients and nutraceuticals. Food and Chemical Toxicology, 46, 2742-2747. http://dx.doi.org/10.1016/j.fct.2008.04.030

Beluhan, S., \& Ranogajec, A. (2011). Chemical composition and non-volatile components of Croatian wild edible mushrooms. Food Chemistry, 124, 1076-1082. http://dx.doi.org/10.1016/j.foodchem.2010.07.081

Bernaś, E., Jaworska, G., \& Lisiewska, Z. (2006). Edible Mushrooms as a Source of Valuable Nutritive Constituents. Acta Scientiarum Polonorum - Technologia Alimentaria, 1, 5-20.

Bradford, M. M. (1976). A rapid and sensitive method for the quantitation of microgram quantities of protein utilizing the principle of protein-dye binding. Analytical Biochemistry, 72, 248-254. http://dx.doi.org/10.1016/0003-2697(76)90527-3

Buswell, J.; Cai, Y. J. \& Chang, S.T. ( 1995). Effect of nutrient nitrogen and manganese or manganese peroxidase and laccase production by Lentinula (Lentinus) edodes. Fems Microbiology Letter, 128, 81-88. http://dx.doi.org/10.1016/0378-1097(95)00087-L

Carbonero, E. R., Gracher, A. H. P., Smiderle, F. R., Rosado, F. R., Sassaki, G. L., Gorin, P. A. J., \& Iacomini, M. (2006). A [beta]-glucan from the fruit bodies of edible mushrooms Pleurotus eryngii and Pleurotus ostreatoroseus. Carbohydrate Polymers, 66, 252-257. http://dx.doi.org/10.1016/j.carbpol.2006.03.009

Chandel, G., Banerjee, S., See, S., Meena, R., Sharma, D. J., \& Verulkar, S. B. (2010). Effects of different nitrogen fertilizer levels and native soil properties on rice grain $\mathrm{Fe}, \mathrm{Zn}$ and protein contents. Rice Science, 17, 213-227. http://dx.doi.org/10.1016/S1672-6308(09)60020-2

Ferrise, R., Triossi, A., Stratonovitch, P., Bindi, 222 M., \& Martre, P. (2010). Sowing date and nitrogen fertilisation effects on dry matter and nitrogen dynamics for durum wheat: An experimental and simulation study. Field Crops Research, 117, 245-257. http://dx.doi.org/10.1016/j.fcr.2010.03.010

Curvetto, N. R., Figlas, D., Devalis, R., \& Delmastro S. (2002). Growth and productivity of different Pleurotus ostreatus strains on sunflower seed hulls supplemented with $\mathrm{N}-\mathrm{NH}_{4}{ }^{+}$and/or Mn(II). Bioresource Technology, 84, 171-176. http://dx.doi.org/10.1016/S0960-8524(02)00013-5

Ghorai, S., Banik, S. P., Verma, D., Chowdhury, S., Mukherjee, S., \& Khowala, S. (2009). Fungal biotechnology in food and feed processing. Food Research International, 42, 577-587. http://dx.doi.org/10.1016/j.foodres.2009.02.019

Guo, L.-Q., Lin, J.-Y., \& Lin, J.-F. (2007). Non-volatile components of several novel species of edible fungi in China. Food Chemistry, 100, 643-649. http://dx.doi.org/10.1016/j.foodchem.2005.09.087

Jafarpour, M., Zand, A. J., Dehdashtizadeh, B., \& Eghbalsaied, S. (2010). Evaluation of agricultural wastes and food supplements usage on growth characteristics of Pleurotus ostreatus. African Journal of Agricultural Research, 5, 3291-3296.

Janicki, F. J., Holter, J. B., \& Hayes, H. H. (1985). Varying protein content and nitrogensolubility for Pluriparous, Lactating Holstein Cows: Digestive performance duringearly lactation. Journal of Dairy Science, 68, 1995-2008. http://dx.doi.org/10.3168/jds.S0022-0302(85)81061-4

Jedinak, A., Dudhgaonkar, S., Jiang, J., Sandusky, G., \& Sliva, D. (2010). Pleurotus ostreatus inhibits colitis-related colon carcinogenesis in mice. International Journal of Molecular Medicine, 26, 643-650. http://dx.doi.org/10.3892/ijmm_00000509 
Kalac, P. (2009). Chemical composition and nutritional value of European species of wild growing mushrooms: A review. Food Chemistry, 113, 9-16. http://dx.doi.org/10.1016/j.foodchem.2008.07.077

Khan, N. K., Watanabe, M., \& Watanabe, Y. (2000). Effect of partial urea application on nutrient absorption by hydroponically grown Spinach (Spinacia oleracea L.). Soil Science Plant Nutrition, 46, 199-208.

Loss, E., Royer, A. R., Barreto-Rodrigues, M., \& Barana, A. C. (2009). Use of maize wastewater for the cultivation of the Pleurotus spp. mushroom and optimization of its biological efficiency. Journal of Hazardous Materials, 166, 1522-1525. http://dx.doi.org/10.1016/j.jhazmat.2008.11.014

Manzi, P., \& Pizzoferrato, L. (2000). Beta-glucans in edible mushrooms. Food Chemistry, 68, 315-318. http://dx.doi.org/10.1016/S0308-8146(99)00197-1

Membrillo, I., Sánchez, C., Meneses, M., Favela, E., \& Loera, O. (2008). Effect of substrate particle size and additional nitrogen source on production of lignocellulolytic enzymes by Pleurotus ostreatus strains. Bioresource Technology, 99, 7842-7847. http://dx.doi.org/10.1016/j.biortech.2008.01.083

Membrillo, I., Sánchez, C., Meneses, M., Favela, E., \& Loera, O. (2011). Particle geometry affects differentially substrate composition and enzyme profiles by Pleurotus ostreatus growing on sugar cane bagasse. Bioresource Technology, 102, 1581-1586. http://dx.doi.org/10.1016/j.biortech.2010.08.091,

Moonmoon, M., Shelly, N. J., Khan, M. A., Uddin, M. N., Hossain, K., Tania, M., \& Ahmed, S. (2011). Effects of different levels of wheat bran, rice bran and maize powder supplementation with saw dust on the production of shiitake mushroom (Lentinus edodes (Berk.) Singer). Saudi Journal of Biological Sciences, 18, 323-328 . http://dx.doi.org/10.1016/j.sjbs.2010.12.008

Murphy, J., \& Riley, J. P. (1962). A modified single solution method for the determination of phosphate in natural waters. Analytica Chimica Acta, 27, 31-36. http://dx.doi.org/10.1016/S0003-2670(00)88444-5

Özçelik, E., \& Peksen, A. (2007). Hazelnut husk as a substrate for the cultivation of shiitake mushroom (Lentinula edodes). Bioresource Technology, 98, 2652-2658. http://dx.doi.org/10.1016/j.biortech.2006.09.020

Papaspyridi, L.-M., Katapodis, P., 266 Gonou-Zagou, Z., Kapsanaki-Gotsi, E., \& Christakopoulos, P. (2010). Optimization of biomass production with enhanced glucan and dietary fibres content by Pleurotus ostreatus ATHUM 4438 under submerged culture. Biochemical Engineering Journal, 50, 131-138. http://dx.doi.org/10.1016/j.bej.2010.04.008

Park, Y. K., Ikegakim, M., Alencar, S. M., \& Aguiar, C. L. (2003). Determination of $\beta$ - glucan concentration in Agaricus blazei Murill mushroom by enzymatic method. Ciência e Tecnologia de Alimentos, 23, 312-316. http://dx.doi.org/10.1590/S0101-20612003000300003

Paul, R., Singh, V., Tyagi, R., Singh, A., \& Dubey, D. (2010). Micro-Elements work for the growth and total soluble protein production in Aspergillus niger at different concentrations. Journal of Pure and Applied Microbiology, 4, 293-296.

Shashirekha, M. N., Rajarathnam, S., \& Bano, Z. (2005). Effects of supplementing rice straw growth substrate with cotton seed on the analytical characteristics of the mushroom, Pleurotus florida (Block \& Tsao). Food Chemistry, 92, 255-259. http://dx.doi.org/10.1016/j.foodchem.2004.07.034

Silva, M. C. S., Naozuka, J., da Luz, J. M. R., de Assunção, L. S., Oliveira, P.V., Vanetti, M. C. D., Bazzolli, D. M. S., Kasuya, M. C. M. (2012). Enrichment of Pleurotus ostreatus mushrooms with selenium in coffee husks. Food chemistry, 131, 558-563. http://dx.doi.org/10.1016/j.foodchem.2011.09.023

Tedesco, M. J., Gianello, C., Bissani, C. A., Bohnen, H., \& Volkweiss, S. J. (1995). Análises de solo, plantas e outros materiais (2th ed.). Porto Alegre: Departamento de Solos, UFRGS.

Tewari, R. P. (1986). Mushroom cultivation. Extension Bulletin. Indian Institute of Horticulture Research, 8, 36.

Thiers, R. E., \& Hviid, K. (1962). Interference--free flame photometry of Calcium in serum and urine. Clinical Chemistry, 8, 35-46.

Tshinyangu, K. K., \& Hennebert, G. L. (1996). Protein and chitin nitrogen contents and protein content in Pleurotus ostreatus var. columbinus. Food Chemistry, 57, 223-227. http://dx.doi.org/10.1016/0308-8146(95)00202-2

Wang, D., Sakoda, A., \& Suzuki, M. (2001). Biological efficiency and nutritional value of Pleurotus ostreatus

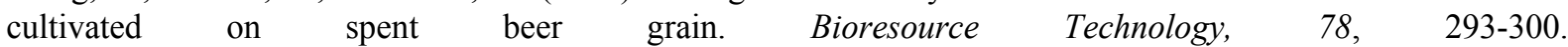
http://dx.doi.org/10.1016/S0960-8524(01)00002-5 
Wasser, S. P., (2002) medicinal mushrooms as a source of antitumor and immunomodulating polysaccharides. Applied Microbiology and Biotechnology, 60, 258-274. http://dx.doi.org/10.1007/s00253-002-1076-7

Wasser, S. (2011). Current findings, future trends, and unsolved problems in studies of medicinal mushrooms. Applied Microbiology and Biotechnology, 89, 1323-1332. http://dx.doi.org/10.1007/s00253-010-3067-4

Table 1. Materials used as substrates for the production of Pleurotus ostreatus mushrooms

\begin{tabular}{ll}
\hline & \multicolumn{1}{c}{ Agroindustrial residues (substrates) } \\
\hline Es & Eucalypt sawdust \\
EsRb & Es + Rice bran $(20 \%$ w/w) \\
EsUr & Es + Urea $(0.5 \% \quad$ w/w $)$ \\
$\mathrm{Co}$ & Corncob \\
$\mathrm{CoRb}$ & Co + Rice bran $(20 \% \quad$ w/w $)$ \\
$\mathrm{CoUr}$ & $\mathrm{C}+$ Urea $(0.5 \% \quad$ w/w $)$ \\
$\mathrm{Eb}$ & Eucalypt bark \\
$\mathrm{EbRb}$ & $\mathrm{Eb}+$ Rice bran $(20 \% \quad$ w/w $)$ \\
$\mathrm{EbUr}$ & Eb + Urea $(0.5 \% \quad$ w/w $)$ \\
$\mathrm{Ch}$ & $\mathrm{Coffee} \mathrm{husk}$ \\
$\mathrm{ChRb}$ & $\mathrm{Ch}+$ Rice bran $(20 \% \quad$ w/w $)$ \\
$\mathrm{ChUr}$ & $\mathrm{Ch}+$ Urea $(0.5 \% \quad$ w/w $)$ \\
$\mathrm{Sb}$ & $\mathrm{Sugarcane}$ bagasse \\
$\mathrm{SbRb}$ & $\mathrm{Sb}+$ Rice bran $(20 \% \quad$ w/w $)$ \\
$\mathrm{SbUr}$ & $\mathrm{Sb}+$ Urea $(0.5 \% \quad$ w/w $)$ \\
\hline
\end{tabular}

Table 2. Mineral composition (as a percentage of dry mass) of $P$. ostreatus mushrooms grown in various substrates that were supplemented with rice bran or urea

\begin{tabular}{|c|c|c|c|c|c|c|c|c|c|}
\hline \multirow{4}{*}{$\begin{array}{c}\text { Substrat } \\
\text { es* }\end{array}$} & \multicolumn{9}{|c|}{ Percentage of minerals in mushrooms } \\
\hline & \multicolumn{3}{|c|}{ Magnesium** } & \multicolumn{6}{|c|}{ Potassium } \\
\hline & \multicolumn{3}{|c|}{ PLO 2 and PLO 6} & \multicolumn{3}{|c|}{ PLO 2} & \multicolumn{3}{|c|}{ PLO 6} \\
\hline & $\begin{array}{c}\text { Contr } \\
\text { ol }\end{array}$ & $\begin{array}{l}\text { Rice } \\
\text { bran }\end{array}$ & Urea & $\begin{array}{c}\text { Contr } \\
\text { ol }\end{array}$ & $\begin{array}{l}\text { Rice } \\
\text { bran }\end{array}$ & Urea & $\begin{array}{c}\text { Contr } \\
\text { ol }\end{array}$ & $\begin{array}{l}\text { Rice } \\
\text { bran }\end{array}$ & Urea \\
\hline Es & $0.17^{\mathrm{A}}$ & $0.16^{\mathrm{A}}$ & $0.14^{\mathrm{B}}$ & $2.63^{\mathrm{A}}$ & $2.23^{\mathrm{A}}$ & $1.86^{\mathrm{B}}$ & $2.42^{\mathrm{A}}$ & $2.41^{\mathrm{A}}$ & $1.39^{\mathrm{B}}$ \\
\hline Co & $0.13^{\mathrm{A}}$ & $0.13^{\mathrm{A}}$ & $0.13^{\mathrm{A}}$ & $2.10^{\mathrm{A}}$ & $1.92^{\mathrm{B}}$ & $1.95^{\mathrm{A}}$ & $2.02^{\mathrm{A}}$ & $1.82^{\mathrm{A}}$ & $1.81^{\mathrm{A}}$ \\
\hline $\mathrm{Eb}$ & $0.16^{\mathrm{A}}$ & $0.14^{\mathrm{B}}$ & $0.13^{\mathrm{B}}$ & $2.13^{\mathrm{A}}$ & $2.48^{\mathrm{A}}$ & $1.63^{\mathrm{B}}$ & 2.00 & $2.07^{\mathrm{A}}$ & $1.75^{\mathrm{B}}$ \\
\hline $\mathrm{Ch}$ & $0.13^{\mathrm{B}}$ & $0.15^{\mathrm{A}}$ & $0.11^{\mathrm{B}}$ & 2.27 & $2.34^{\mathrm{A}}$ & $2.14^{\mathrm{B}}$ & $2.23^{\mathrm{A}}$ & $2.42^{\mathrm{A}}$ & $2.15^{\mathrm{A}}$ \\
\hline \multirow[t]{2}{*}{$\mathrm{Sb}$} & $0.17^{\mathrm{A}}$ & $0.16^{\mathrm{A}}$ & $0.16^{\mathrm{A}}$ & $2.48^{\mathrm{A}}$ & $2.24^{\mathrm{A}}$ & $2.43^{\mathrm{A}}$ & $2.70^{\mathrm{A}}$ & $2.14^{\mathrm{B}}$ & $2.36^{\mathrm{B}}$ \\
\hline & \multicolumn{3}{|c|}{ Phosphorus** } & \multicolumn{6}{|c|}{ Calcium $* * *$} \\
\hline Es & $1.38^{\mathrm{A}}$ & $1.14^{\mathrm{B}}$ & $0.91^{\mathrm{C}}$ & \multicolumn{6}{|c|}{0.0159} \\
\hline Co & $0.82^{\mathrm{B}}$ & $1.50^{\mathrm{A}}$ & $0.58^{\mathrm{C}}$ & \multicolumn{6}{|c|}{0.0043} \\
\hline $\mathrm{Eb}$ & $1.00^{\mathrm{B}}$ & $1.25^{\mathrm{A}}$ & $0.65^{\mathrm{c}}$ & \multicolumn{6}{|c|}{0.0131} \\
\hline $\mathrm{Ch}$ & $0.64^{\mathrm{B}}$ & $1.50^{\mathrm{A}}$ & $0.57^{\mathrm{B}}$ & \multicolumn{6}{|c|}{0.0056} \\
\hline $\mathrm{Sb}$ & $1.64^{\mathrm{A}}$ & $1.61^{\mathrm{A}}$ & $1.32^{\mathrm{B}}$ & \multicolumn{6}{|c|}{0.0054} \\
\hline
\end{tabular}

Means followed by different letters within the same line differ at Tukey's test $(\mathrm{P}<0.05)$.

* See table $1, * *$ Not significantly different between the strains $(\mathrm{P}<0.05)$, *** Not significantly different between the strains and nitrogen supplementation $(\mathrm{P}<0.05)$. Control $=$ without nitrogen supplementation. 
Table 3. Total protein (as a percentage of dry weight) of $P$. ostreatus mushrooms grown in various substrates that were supplemented with rice bran or urea

\begin{tabular}{llll|lll}
\hline \multirow{2}{*}{ Substrates* } & \multicolumn{3}{c}{ Total protein** } \\
\cline { 2 - 7 } & \multicolumn{3}{c}{ PLO2 } & \multicolumn{3}{c}{ PLO6 } \\
\cline { 2 - 7 } & Control & Rice bran & Urea & Control & Rice bran & Urea \\
\hline Es & $28.60^{\mathrm{A}}$ & $22.86^{\mathrm{B}}$ & $22.56^{\mathrm{B}}$ & $27.38^{\mathrm{A}}$ & $27.68^{\mathrm{A}}$ & $18.75^{\mathrm{B}}$ \\
$\mathrm{Co}$ & $20.28^{\mathrm{A}}$ & $20.45^{\mathrm{A}}$ & $17.48^{\mathrm{A}}$ & $20.02^{\mathrm{A}}$ & $21.81^{\mathrm{A}}$ & $20.63^{\mathrm{A}}$ \\
$\mathrm{Eb}$ & $19.40^{\mathrm{A}}$ & $20.98^{\mathrm{A}}$ & $19.80^{\mathrm{A}}$ & $21.16^{\mathrm{A}}$ & $17.13^{\mathrm{B}}$ & $21.64^{\mathrm{A}}$ \\
$\mathrm{Ch}$ & $23.35^{\mathrm{A}}$ & $21.90^{\mathrm{A}}$ & $25.32^{\mathrm{A}}$ & $23.83^{\mathrm{A}}$ & $21.81^{\mathrm{A}}$ & $25.40^{\mathrm{A}}$ \\
$\mathrm{Sb}$ & $22.29^{\mathrm{B}}$ & $20.15^{\mathrm{B}}$ & $29.78^{\mathrm{A}}$ & $27.16^{\mathrm{A}}$ & $18.26^{\mathrm{B}}$ & $26.50^{\mathrm{A}}$ \\
\hline
\end{tabular}

Means followed by different letters within the same line differ at Tukey's test $(\mathrm{P}<0.05)$.

Control $=$ without nitrogen supplementation. $*$ See table $1, * *$ Nitrogen correction factor used $=4.38$.

Table 4. Soluble protein ( $\mathrm{mg} \mathrm{g}^{-1}$ dry weight) and $\beta$-glucan (percentage of dry weight) concentrations in $P$. ostreatus mushrooms grown in various substrates that were supplemented with rice bran or urea

\begin{tabular}{lcccccc}
\hline Nitrogen supplementation & \multicolumn{2}{c}{ Soluble protein* } & \multicolumn{3}{c}{$\beta$-glucans* } \\
\hline Control & 8.558 & B & 22.99 & B \\
Rice Bran & 8.419 & B & 27.79 & A & \\
Urea & 9.305 & A & 27.05 & A
\end{tabular}

Means followed by different letters within the same line differ at Tukey's test $(\mathrm{P}<0.05)$.

* Not significantly different between the strains and substrates $(\mathrm{P}<0.05)$.

Control $=$ without supplementation.

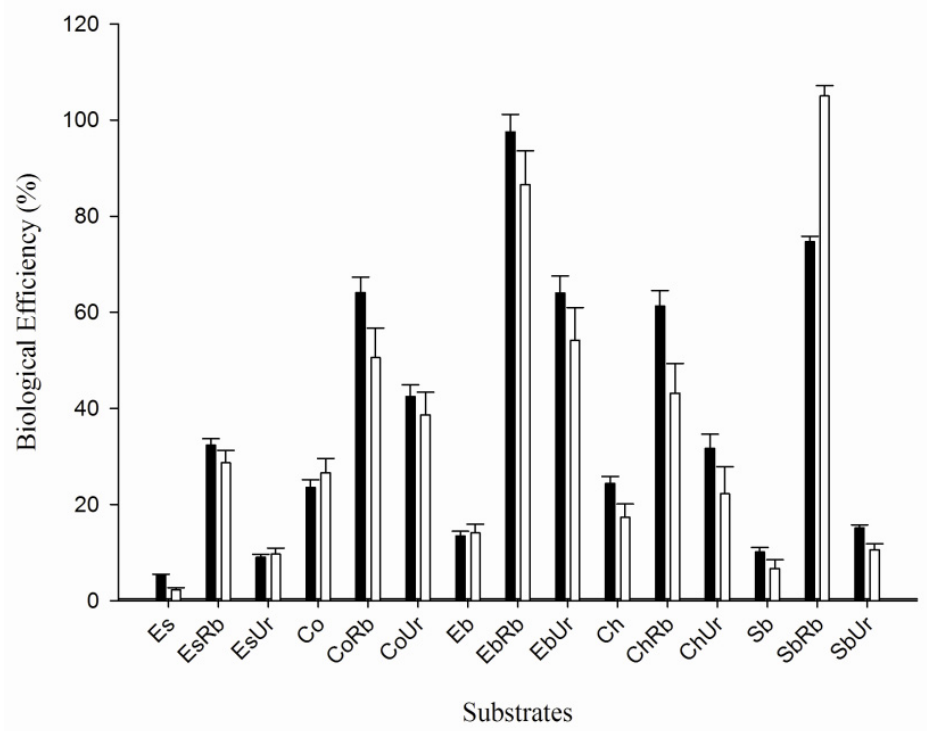

Figure 1. Biological efficiency of P. ostreatus (PLO 2 strain in black and PLO 6 strain in white) strains grown in different substrates supplemented with rice bran or urea. The following abbreviations are used: Es, eucalypt sawdust; Co, corncob; Eb, eucalypt bark; Ch, coffee husk; Sb, sugarcane bagasse; Rb, rice bran supplementation; and Ur, urea supplementation. These data represent the means $\pm \operatorname{sd}(n=5)$ 